\title{
Thermal tolerance of allis shad (Alosa alosa) embryos and larvae: Modeling and potential applications
}

\author{
Philippe JATteau ${ }^{1, \text { a }}$, Hilaire DrouineaU ${ }^{1}$, Katia CHARLES ${ }^{1}$, Laurent CARRY $^{2}$, Frédéric LANGE ${ }^{3}$ \\ and Patrick LAMBERT ${ }^{1}$ \\ 1 Irstea, EABX, Unité de recherches Ecosystèmes Aquatiques et Changements Globaux, 50 avenue de Verdun, Gazinet Cestas, \\ 33612 Cestas, France \\ 2 Association MIGADO, 18 Ter rue de la Garonne, BP 95, 47520 Le Passage, France \\ 3 INRA, UMR ECOBIOP, Quartier Ibarron, 64310 Saint-Pée-sur-Nivelle, France
}

Received 18 May 2016; Accepted 27 November 2016

\begin{abstract}
The objective of this study was to assess the potential effects of climate change on the survival of allis shad early life history stages. Embryos and larvae were exposed to temperatures ranging from 5 to $35^{\circ} \mathrm{C}$. No embryonic survival was recorded at extreme temperatures $\left(\leqslant 10\right.$ and $\left.\geqslant 30^{\circ} \mathrm{C}\right)$, and no larval survival was observed at 5 or $35^{\circ} \mathrm{C}$. Based on these experimental results, a survival model was developed to predict survival rates at different temperatures for embryos and larvae up to 14 days post hatch. The model confirmed that embryonic daily survival is more impacted by temperature than larval survival. The highest survival rates (greater than $80 \%$ ) were found for temperatures between 15.7 and $25.6{ }^{\circ} \mathrm{C}$ for embryos and between 14.6 and $26.7^{\circ} \mathrm{C}$ for larvae. This survival model can be used to explore the impact of temperature on recruitment of allis shad in southern France. Preliminary analysis from two different rivers suggests that cold temperatures may have a strong impact on embryonic and larval survival.
\end{abstract}

Keywords: Alosa alosa / thermal tolerance / embryo / larvae / survival analysis

\section{Introduction}

Individuals facing ongoing global warming may respond with physiological modifications such as metabolic and developmental rates (Hughes 2000).Temperature greatly influences metabolism, life history traits and biological processes (Brown et al. 2004), and understanding a population's thermal sensitivity is crucial to predict its survival in a given environment. Thermal tolerance generally increases as individuals progress from embryonic to adult phases (Coutant 1987; Elliott and Elliott 2010; Souchon and Tissot 2012). Therefore, survival at early developmental stages could influence population persistence as temperatures continue to increase (Delage et al. 2014; Ziegeweid et al. 2008) due to climate change.

The allis shad Alosa alosa was originally distributed along the Atlantic coast from Norway to Morocco (Baglinière 2000). All stocks of this anadromous fish have declined in recent decades, thereby resulting in a contraction of its distribution range (Baglinière 2000). The allis shad is now found from the northern coastal rivers of Normandy (France) (Lassalle et al. 2008) to Portuguese rivers (ICES 2015). Anthropogenic activities, such as damming, pollution, habitat degradation and overfishing, are the primary causes of this decline (Taverny

\footnotetext{
${ }^{a}$ Corresponding author: philippe.jatteau@irstea.fr
}

et al. 2000a). This species is currently classified as vulnerable by the International Union for Conservation of Nature (IUCN) Red List of Threatened Species and is protected across Europe (Habitat Directive, Annexes II and V; the Convention for the Protection of the Marine Environment of the North-East Atlantic (OSPAR Convention), Annex V; Berne Convention, Annex III). The Gironde basin was formerly considered to be the most important habitat for allis shad in Europe (Martin Vandembulcke 1999; Chanseau et al. 2005); however the population recently collapsed (Rougier et al. 2012). Recruitment failure was suspected as the primary cause of the collapse (Rougier et al. 2012). Indeed juvenile abundance has markedly declined since 2000, and the adult abundance has declined since 2005 (M. Girardin, unpubl. data). However, no clear evidence of the possible causes of the decline are presently available. In response fishing authorities enforced a moratorium in the Gironde basin in 2008. Such declines were also observed in other watersheds from the southern part of the distribution area, from Portugal (Stratoudakis et al. 2016) to Morocco (Sabatie and Bagliniere 2001). In the Nivelle River, a watershed close to the Gironde, the population has shown a similar marked decline, with abundance estimates in 2015 10\% lower than the average observed in the 15 previous years (Migradour, unpubl. data). 
In contrast, abundances have tended to increase in the northernmost watersheds, such as in the Vire watershed. The declines in the south and increases in the north may indicate a shift of distribution area due to climate change (Rougier et al. 2014).

Shad survival at early developmental stages is related to environmental factors, and there are direct consequences on year-class strength (Crecco et al. 1983). More specifically, larval survival is affected by temperature (Crecco and Savoy 1985; Savoy and Crecco 1988; Aprahamian and Aprahamian 2001).

In the specific case of allis shad, temperature is one of the main environmental driver of the species distribution (Béguer et al. 2007) and regulates several phases in life history, such as adult migration (Rochard 2001), spawning (Cassou-Leins et al. 2000), egg development (Taverny et al. 2000b) and juvenile migration (Boisneau et al. 2008). However, there have been no published studies on the survival and upper tolerance limits of the allis shad.

This study aimed to assess thermal tolerance of allis shad. Firstly, incubation duration with respect to temperature and thermal tolerance of embryos and larvae were assessed in laboratory experiments. Secondly, a survival model (Cox and Oakes 1984) was fitted to the experimental results to predict the survival rates of allis shad embryos and larvae with respect to temperature. Finally, a thermal tolerance curve for shad early life stages is determined.

\section{Materials and methods}

The experimental protocol supervisor fulfilled all legal requirements for animal experimentation. Experiments were performed at the Irstea experimental station (authorization for experiments on animals A33-478-001).

\section{Controlled reproduction}

Embryos and larvae were obtained from spawning occurring in tanks (Hendricks 2003). Spawners were captured at the Uxondoa trap on the Nivelle River (southwestern France) (Fig. 1). The fish were transported back to the Irstea experimental station (Saint-Seurin/Isle, France). Once in captivity they received hormonal stimulation (LHRHa des-GLY ${ }^{10}$, $\left[\mathrm{D}-\mathrm{ALA}^{6}\right]$-LHRH ethylamide, Sigma) and were maintained at $20 \pm 1{ }^{\circ} \mathrm{C}$. Eggs were collected in an egg trap located at the tank outflow. The eggs were strained, and three samples were weighed and counted to calculate the number of eggs per gram.

\section{Experimental conditions}

Both the egg incubation and larval rearing were replicated twice for each thermal condition. For the egg incubation experiment, $25 \mathrm{~g}$ of eggs were placed in U-shaped incubators ( $5 \mathrm{~cm}$ in diameter and containing $2 \mathrm{~L}$ of water) within $4 \mathrm{~h}$ of spawning, and the number of eggs was calculated. At each temperature, two incubators were connected to a $10-\mathrm{L}$ tank

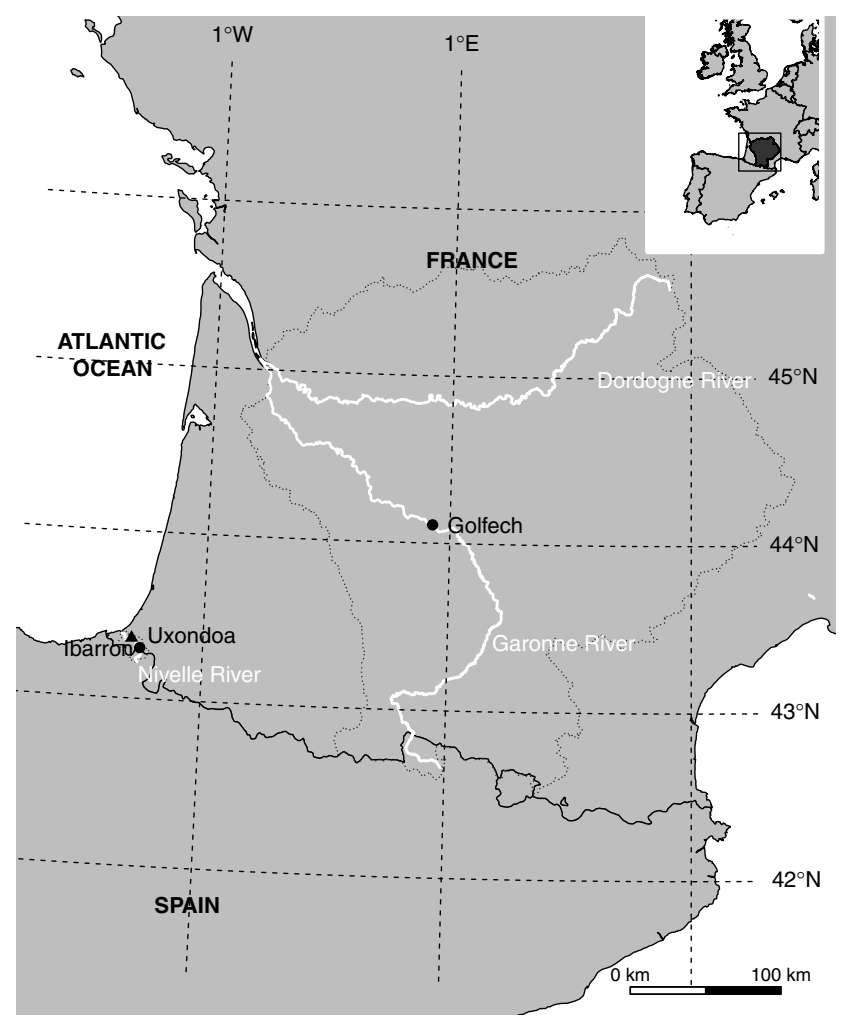

Fig. 1. Location of the study site. Spawners were collected at the Uxondoa fish trap (black triangle) on the Nivelle River. Temperatures were monitored at Ibarron, on the Nivelle River and at the Golfech dam, on the Garonne River (black circle).

with aeration. Heating (Shego, Offenbach am Main, Germany) and chilling (Teco, Ravenna, Italy) systems were managed using a control and display device (Tunze, Penzberg, Germany). Temperature, dissolved oxygen and $\mathrm{pH}$ were recorded every $12 \mathrm{~h}$. The larvae used in the survival study were from the same spawning event and were incubated at $20{ }^{\circ} \mathrm{C}$ in a McDonald jar. Three hundred one-day-old larvae were introduced to each cylindrical rearing tank $(20 \mathrm{~cm}$ in diameter and $30 \mathrm{~cm}$ high $)$. Two rearing systems were connected to a 30-L tank in which water temperature was controlled using a system similar to that used for egg incubation. The larvae were reared in a $16 \mathrm{~L}: 8 \mathrm{D}$ photoperiod to mimic natural conditions during the spawning period and were fed ad libitum 4 times daily with brine shrimp (Artemia salina). The rearing tanks were cleaned daily prior to the first meal.

\section{Thermal tolerance experiment}

Thermal tolerance experiments were conducted at several temperatures over two consecutive years $(15,18,20,21,24$, 27, 30 and $32{ }^{\circ} \mathrm{C}$ in 2008 and $5,10,15,20,25,32$ and $35^{\circ} \mathrm{C}$ in 2009).

After the eggs or larvae were placed in incubators or tanks, gradual increase or decrease of water temperature was undertaken from $20{ }^{\circ} \mathrm{C}$ to the targeted experimental temperatures. A rate of $0.1{ }^{\circ} \mathrm{C} \mathrm{min}^{-1}$ was chosen to prevent individuals 
from acclimating to intermediate temperatures before reaching the targeted temperature (Becker and Genoway 1979; Ziegeweid et al. 2008). The maximum time to reach the experimental temperature was $2 \mathrm{~h} 30 \mathrm{~min}$ for extreme temperatures. Experiments started when the targeted temperatures were reached. Embryonic survival was determined just prior to hatching when embryonic development reached the prehatching stage (i.e. stage observed $95 \mathrm{~h}$ post fertilization at $20{ }^{\circ} \mathrm{C}$ - D. Clavé, unpubl. data). Live embryos were counted to compare survival results during incubation with respect to temperature and were then returned to their incubator and maintained under observation until hatching. Incubation duration, i.e., the time at which first hatching occurred, was recorded for each temperature.

Larval rearing lasted 14 days. Dead larvae were removed and counted daily. At the end of the experiment, live larvae were counted and daily survival was determined.

\section{Modelling thermal tolerance}

A linear model was used to fit a temperature-dependent power function for incubation duration (which later corresponds to embryo stage):

$$
d(T)=\delta_{0} T^{-\delta_{1}},
$$

where $\delta_{0}$ and $\delta_{1}$ are two parameters of the power function between temperature and the time required to achieve a developmental stage (Manel and Debouzie 1997).

Embryo survival was assessed using a logistic regression model with a cubic polynomial of temperature $T$. A random effect $r$ was also added to take into account the variability in replicates.

$$
\log \left(\frac{S_{\text {embryo }}}{1-S_{\text {embryo }}}\right) \sim T+T^{2}+T^{3}+r
$$

with $S_{\text {embryo }}$ the expected proportion of survivors.

The model was fitted on the pre-hatching counts of surviving and dead embryos using the linear mixed effects model procedure (lmer) from the R package lme4 (Bates et al. 2015).

Thermal tolerance of larvae was assessed using a survival model with an exponential distribution (Cox and Oakes 1984). The logarithm of the hazard function $h(t)$ is a cubic polynomial of temperature $T$ added with a random effect $r$ to take into account replicate variability.

$$
\log (h(t)) \sim T+T^{2}+T^{3}+r
$$

This larvae model was fitted on the daily number of dead larvae over 14 days and the number of surviving individuals at the end of the experiment. The model was fitted using the "survreg" procedure from the R package survival (Therneau 2015).

The cubic polynomial in the model gives an asymmetric bell-shaped response function of mortality relative to temperature, in agreement with physiology theory (Thornton and Lessem 1978; Rosso et al. 1995; Brown et al. 2004).

Embryo and larvae models were then used to calculate survival rates at different temperatures for embryo (from

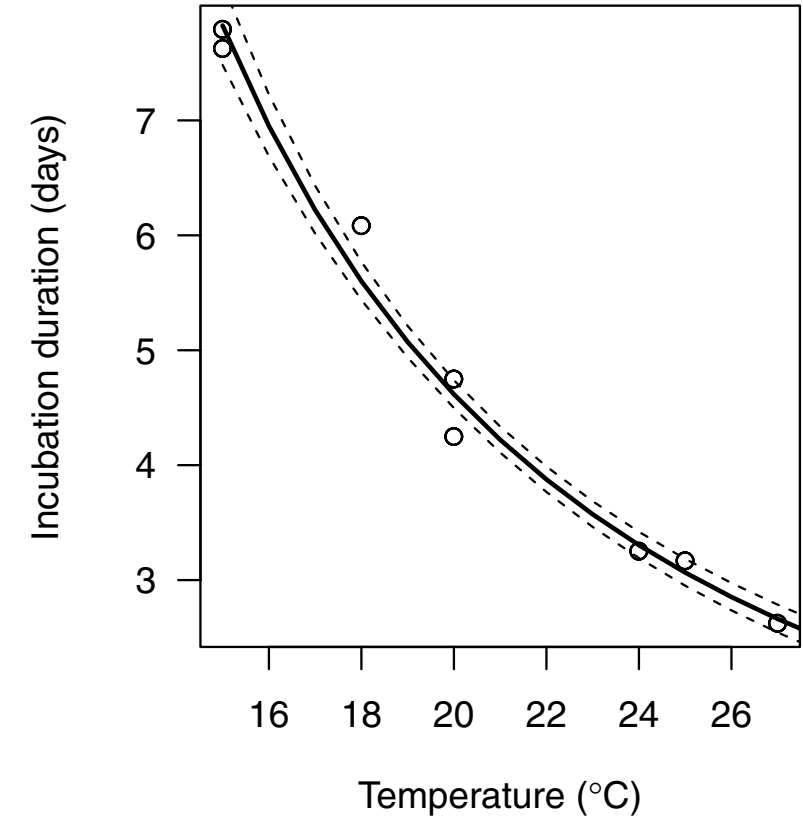

Fig. 2. Incubation duration with respect to temperature. Open circles refer to the experimental data, the solid line represents the power regression and the dashed lines indicate the $95 \%$ confidence interval.

fertilization to hatching), larvae (from hatching to 14 days post hatching (dph)), and from fertilization to $14 \mathrm{dph}$. Optimal and tolerance ranges (Shelford 1931; Frederich and Pörtner 2000) were then defined as the temperature ranges at which the survival rates were higher than $80 \%$ and $5 \%$ of the maximum, respectively (Huey and Stevenson 1979).

\section{Application to field data}

We considered two rivers, the Nivelle River where the spawners came from and the Garonne River, a nearby watershed located $200 \mathrm{~km}$ northeast with a historical large population of allis shad. Mean daily river temperature data for the Nivelle River were recorded at the INRA station located at Ibarron, a few kilometers upstream of the first spawning ground (Fig. 1). For the Garonne River they were recorded at the control station at the Golfech dam fish pass located two kilometers upstream of the main spawning grounds. Spawning acts of allis shad are usually recorded mainly from mid-May to mid-June but can start at the beginning of May and cease by mid-July (Taverny 1991; Cassou-Leins et al. 2000; Acolas et al. 2006).

For the present analyses, we fixed the spawning season for each year to start the 1st of May and finish on the 15th of July and drew the distribution of daily temperatures according to tolerance and optimal ranges.

\section{Results}

\section{Incubation duration}

The incubation duration was plotted against temperature (Fig. 2). The incubation period ranged from 7.6 days at $15^{\circ} \mathrm{C}$ to 2.6 days at $27^{\circ} \mathrm{C}$. 
Table 1. Temperature thresholds for embryos, 14-dph larvae and from fertilization to 14-dph larvae. Optimal temperature $\left(\mathrm{T}_{\mathrm{opt}}\right.$, i.e., temperature at maximum survival), tolerance temperature range (i.e., survival greater than $5 \%, \mathrm{TT}_{\min }$ and $\mathrm{TT}_{\max }$ ), and optimal temperature range (i.e., survival greater than $80 \%, \mathrm{OT}_{\min }$ and $\mathrm{OT}_{\max }$ ).

\begin{tabular}{cccccc}
\hline & \multicolumn{5}{c}{ Tolerance range } \\
\cline { 2 - 5 } & \multicolumn{4}{c}{ Optimal range } & \\
\cline { 2 - 5 } & $\mathrm{TT}_{\text {Min }}$ & $\mathrm{OT}_{\text {Min }}$ & $\mathrm{T}_{\mathrm{Opt}}$ & $\mathrm{OT}_{\text {Max }}$ & $\mathrm{TT}_{\text {Max }}$ \\
\hline Embryos & 9.4 & 15.7 & 20.8 & 25.6 & 30.7 \\
14-dph larvae & 7.6 & 14.6 & 20.7 & 26.7 & 33.0 \\
Embryos to & 10.8 & 16.6 & 20.8 & 24.8 & 29.8 \\
14-dph larvae & & & & &
\end{tabular}

The model explained $98.5 \%$ of the variance and produced the following coefficients (shown with their $95 \%$ confidence intervals):

$$
\begin{aligned}
& \delta_{0}=1124[772 ; 1639] \\
& \delta_{1}=1.83[1.71 ; 1.96] .
\end{aligned}
$$

\section{Embryonic survival}

Mortality was nearly instantaneous at the highest temperatures. No survival was recorded at $2 \mathrm{~h} 30,1 \mathrm{~h} 00$ or $0 \mathrm{~h} 30$ after the start of the experiment for embryos at 30,32 and $35^{\circ} \mathrm{C}$, respectively. For embryos at 5 and $10{ }^{\circ} \mathrm{C}$, development was arrested at the morula or the blastula stage. No survival was recorded $60 \mathrm{~h}$ after the start of the experiment. Survival rates were nearly constant between 15 and $27{ }^{\circ} \mathrm{C}$; they varied from 68 to $87 \%$ in 2008 and from 68 to $76 \%$ in 2009 (Fig. 3a).

Thus, cumulative survival for the embryonic stage is

$$
S_{\text {embryo }}(T)=\frac{1}{\left(1+e^{-1.24+1.12 T-7.83 \times 10^{-3} T^{2}-6.11 \times 10^{-4} T^{3}}\right)} .
$$

\section{Larval survival}

No larval survival was recorded at 5 or $35^{\circ} \mathrm{C}$. The larvae died within four hours at $35{ }^{\circ} \mathrm{C}$, and those reared at $5{ }^{\circ} \mathrm{C}$ remained motionless on the bottom of the tank and suffered total mortality 12 hours after the start of the experiment. Survival at extreme temperatures was $10 \%$ at $10{ }^{\circ} \mathrm{C}, 28 \%$ and $5 \%$ at $32{ }^{\circ} \mathrm{C}$ in 2008 and 2009 respectively. The highest survival rates were obtained at temperatures ranging between 15 and $27^{\circ} \mathrm{C}$ (Fig. 3b). All the survival larvae in each experiment exhibited normal swimming behavior.

The formula for daily larval survival with respect to temperature is

$$
S_{\text {larvae }}(T)=e^{\left(\frac{1}{e^{-1.85}+5.13 \times 10^{-1} T-1.02 \times 10^{-2} T^{2}-7.01 \times 10^{-5} T^{3}}\right)} .
$$

\section{Survival from the embryonic stage to $14 \mathrm{dph}$}

Table 1 summarizes the effects of various temperature thresholds for embryonic and larval stages and for both stages
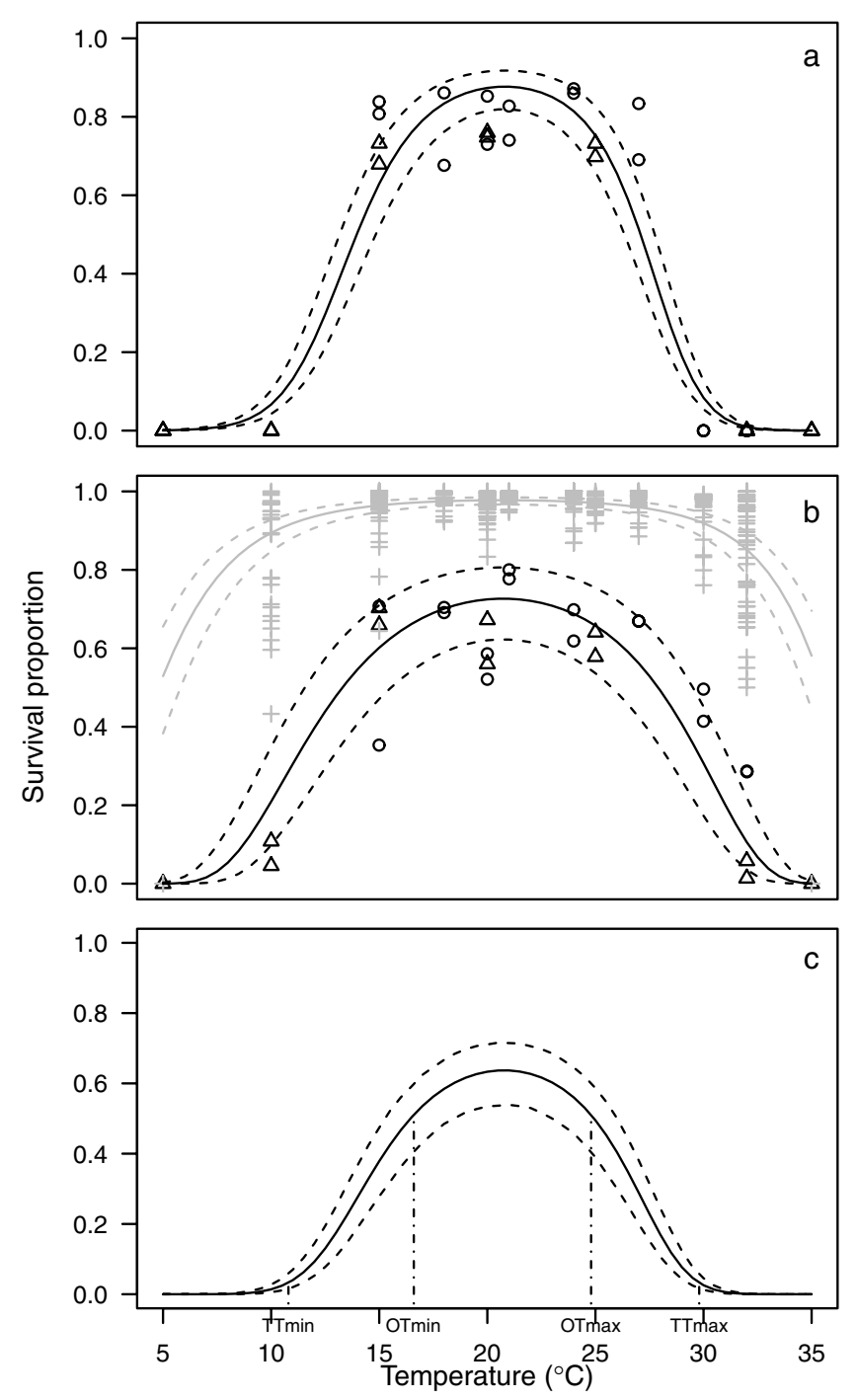

Fig. 3. (a) Embryo survival with respect to temperature, (b) larval survival with respect to temperature and (c) survival from hatching to $14 \mathrm{dph}$ with respect to temperature. Open circles and triangles represent the 2008 and 2009 experimental data respectively, grey lines represent daily survival, and black lines indicate cumulative survival. The solid and dashed lines show the expected survival and the $95 \%$ confidence intervals, respectively. $\mathrm{TT}_{\min }$ and $\mathrm{TT}_{\max }$ define the tolerance range (i.e., at least $5 \%$ survival), and $\mathrm{OT}_{\min }$ and $\mathrm{OT}_{\max }$ define the optimal range (i.e., at least $80 \%$ survival).

combined. The optimal and tolerance temperature ranges for embryos are narrower than those for larvae. The cumulative survival from the embryonic stage to 14 dph larvae (Fig. 3c) indicated an optimal temperature of $20.8^{\circ} \mathrm{C}$ and an optimal range between $16.6{ }^{\circ} \mathrm{C}$ (minimum optimal temperature, $\mathrm{OT}_{\min }$ ) and $24.8^{\circ} \mathrm{C}$ (maximum optimal temperature, $\mathrm{OT}_{\max }$ ). At these temperatures, survival exceeded $80 \%$. Similarly, a tolerance range was identified between $10.8{ }^{\circ} \mathrm{C}$ (minimum tolerance temperature, $\mathrm{TT}_{\min }$ ) and $29.8{ }^{\circ} \mathrm{C}$ (maximum tolerance temperature, $\mathrm{TT}_{\max }$ ), which corresponded to a survival rate of greater than $5 \%$. 

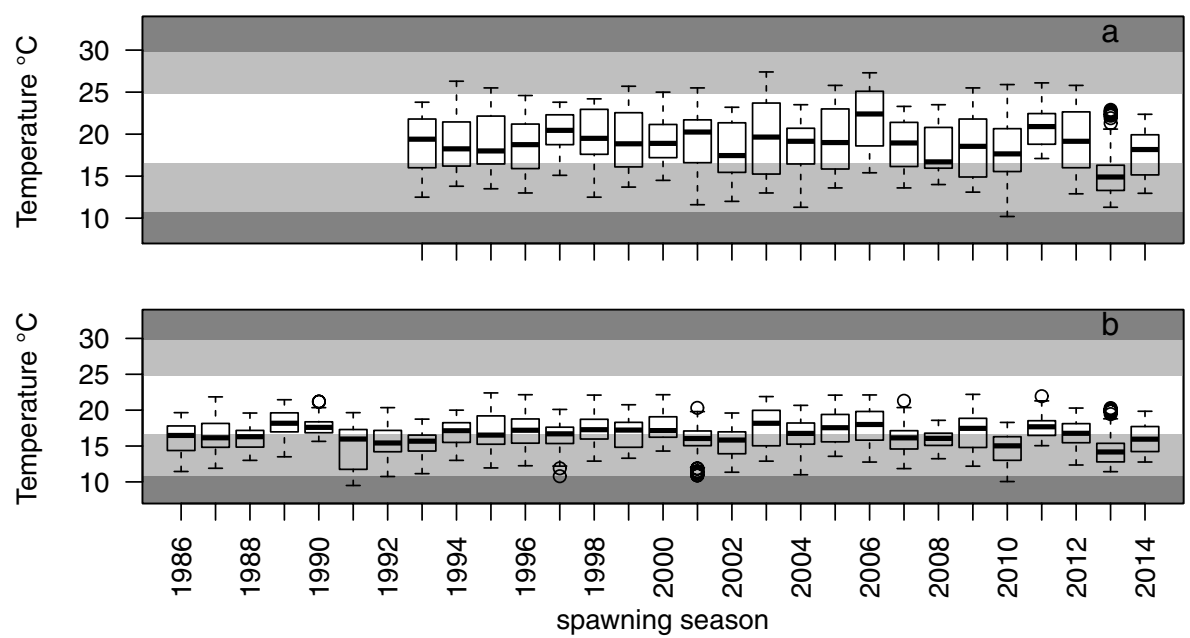

Fig. 4. Distribution of daily temperature between the 1st of May to 15th of July in the Nivelle (a) and the Garonne (b) Rivers. White area indicates temperature within the optimal range, frontiers between dark and light greys indicate the limits of the tolerance range.

\section{Application to field data}

Figure 4 presents the evolution of daily temperature distributions relative to tolerance and optimal ranges for the two studied rivers.

\section{Discussion}

Temperature effects on behaviour, survival and growth have already been studied for many shad species, mainly from North America (Chittenden 1972; Leggett and Whitney 1972; Ross et al. 1993; Navarro et al. 2014). However our results provide the first insights into thermal tolerance and its effects on allis shad embryonic and larval survival. Maximum survival results recorded in this study were within the range of previous studies on other species of shad, either for embryos (Hendricks and Tryninewski 2009) or larvae (Heinrich 1981; Wiggins et al. 1985; Hundt et al. 2015).

Mean daily temperatures data from the field mask the temperature fluctuations throughout the day (Wehrly et al. 2007) and temperature variations at the microhabitat scale. More extreme conditions may be experienced in the field, which could lead to lower survivals. Survival models for embryos or larvae were estimated at constant temperature, while fluctuating temperatures occurred in natural conditions. In this way, the possible acclimation effect during experiments was not taken into account, which could lead to an overestimate of survival. Overall, our experimental protocol probably tends to overestimate survival in nature.

Our experimental results for allis shad embryos are similar to those of North American species in terms of optimal temperature range and upper tolerance limit (Edsall 1970; Kellogg 1982; Klauda et al. 1991; Ross et al. 1993). Incubation duration is primarily related to temperature (Teletchea and Fontaine 2010), and an extremely large difference in incubation duration (i.e., the longest was 3.5-fold the duration of the shortest) was observed between extreme temperatures. The model predicted more than $80 \%$ of the maximal survival between 15.7 and $25.6{ }^{\circ} \mathrm{C}$, but survival rates fell below $5 \%$ of the maximum survival at temperatures lower than $9.4^{\circ} \mathrm{C}$ and higher than 30.7 (Table 1).

Moreover, temperature reductions in wild populations result in longer incubation times and a concomitant increase in mortality risk due to predation or climatic events (Kamler et al. 1998; Esteves and Andrade 2008); these may consequently reduce survival.

The optimal range of temperature for larvae determined in this study is in agreement with Hundt et al. (2015) where there was no difference in mortality after $11 \mathrm{dph}$ for the temperatures tested between 16 and $28{ }^{\circ} \mathrm{C}$. Our experimental results for larvae were also similar to those of North American species (Klauda et al. 1991; Ross et al. 1993). However, optimal survival for Alosa fallax larvae was found at temperatures greater than $24{ }^{\circ} \mathrm{C}$ (Navarro et al. 2014) which indicates that this species persists at higher optimal temperatures than allis shad. The model predicted larval survival greater than $80 \%$ between 14.6 and $26.7{ }^{\circ} \mathrm{C}$. The larvae appeared to be more tolerant to extreme temperatures than the eggs (Fig. 3 and Table 1). This finding is generally observed and agrees with that of Brett (1970, in Blaxter 1992) who demonstrated that embryos exhibited a narrower temperature tolerance range than larvae.

Thermal tolerance curves are often asymmetric with a more abrupt decline of survival at high or low temperature (Thornton and Lessem 1978; Angilletta et al. 2002). In our results, this asymmetry is limited because only a few experiments were performed at extreme temperatures, and they provide very different results in 2008 and 2009. Those differences in survival at high temperatures in 2008 and 2009 could be due to differences of wild-caught spawners maturity levels, which is known to subsequently influence gamete quality in tank spawning (Fletcher et al. 2001). However, the slope of the thermal tolerance is more abrupt at high temperature than at low temperature with an optimal temperature $0.75^{\circ} \mathrm{C}$ and $0.4{ }^{\circ} \mathrm{C}$ higher than the middle of the tolerance range for embryo and larvae respectively. This would imply that a progressive increase of temperature, as in a context of climate change, can have a faster impact on first stages survival. 
The survival rate from the embryonic stage to $14 \mathrm{dph}$ reported in this study is obviously high compared with survival rates observed in the field. Extremely low survival rates have been reported from the embryonic phase in the field: $0.5 \%$ survival for the allis shad (P. Jatteau, unpubl. data) and 4\% for the American shad Alosa sapidissima (Savoy and Crecco 1988). Survival rates of larvae in the field are similarly low: $1 \%$ survival of blueback herring Alosa aestivalis larvae between 4 and 8 days post-hatching (Walsh et al. 2005) and 2\% survival of American shad larvae between 4 and $30 \mathrm{dph}$ (Crecco et al. 1983). In natural conditions, these low survival rates could be explained by combinations of numerous negative biotic or abiotic factors, such as river discharge, dissolved oxygen, prey availability and predation (Crecco and Savoy 1984; Crecco and Savoy 1985; Limburg 2001; Esteves and Andrade 2012). Since our results only give indications of temperature effects on the survival young stages, those discrepancies are not surprising.

A direct application of the thermal thresholds to daily river temperatures from Nivelle and Garonne rivers showed that cold temperatures were more likely to affect young stages survival than warm temperatures, though behavior may limit this effect by preventing shads to lay eggs at too cold temperatures as observed in other rivers (Acolas et al. 2006). The fact that allis shad did not postpone reproduction (to take advantage of warmer temperature) could be explained by a possible adaptive trade-off between river survival and estuarine survival. Preliminary laboratory experiments for 3-month-old juvenile have shown high sensitivity to hypoxia at $25^{\circ} \mathrm{C}$ (Jatteau and Fraty 2012), conditions that were occasionally recorded during summer migration of allis shad in the Gironde estuary (Lanoux et al. 2013). In delaying reproduction, estuarine conditions encountered during downstream migration could be less suitable.

Surprisingly, thermal conditions in the Nivelle River where the spawners used in this study originated from are less suitable for embryo and larval survival that those in the Garonne River.

In conclusion, our results define the tolerance and optimal thermal ranges for allis shad embryo and larvae. The application of these ranges to field temperatures during the spawning period indicate a possible limiting survival due to low temperature. Therefore, our results suggest that survival of young shads is not likely to be affected, at least in the short terms, by global warming. However, other factors of global changes, such as irrigation, water extraction for human consumption, lead to a reduction in river discharge which may exacerbate temperature increase. Moreover, the asymmetry in the response curve, though limited, may lead to rapid shifts when temperatures will approach the upper limit of tolerance range. Similar analyses for 3 month old juveniles are needed for a full explanation of recruitment variability at the basin level. This approach of modeling opens perspectives to provide a tool to analyze the "thermal history" undergone in natural environment by embryos and larvae.

Acknowledgements. This work was conducted with the financial support of the Conseil Régional d'Aquitaine, Agence de l'Eau AdourGaronne, ONEMA, and FEDER. We would like to thank the Migradour Association, and the AAPPMA of the Nivelle River for their assistance with capturing adult allis shad. We also thank the staff at the experimental station at Irstea. We thank two anonymous referees for their constructive comments which allowed to improve the manuscript.

\section{References}

Acolas M.L., Veron V., Jourdan H., Begout M.L., Sabatie M.R., Bagliniere J.L., 2006, Upstream migration and reproductive patterns of a population of allis shad in a small river (L'Aulne, Brittany, France). ICES J. Mar. Sci. 63, 476-484.

Angilletta M.J., Niewiarowski P.H., Navas C.A., 2002, The evolution of thermal physiology in ectotherms. J. Therm. Biol. 27, 249268.

Aprahamian M.W., Aprahamian C.D., 2001, The influence of water temperature and flow on year class strength of twaite shad (Alosa fallax fallax) from the River Severn, England. Bull. Fr. Pech. Piscic. 362/363, 953-972.

Baglinière J.L., 2000, Le genre Alosa sp. In: Baglinière J.L., Elie P. (Eds.), Les aloses (Alosa alosa et Alosa fallax spp.) - Ecobiologie et variabilité des populations. Paris, INRA - CEMAGREF, pp. 330.

Bates D., Maechler M., Bolker B.M., Walker S.C., 2015, Fitting Linear Mixed-Effects Models Using lme4. Journal of Statistical Software 67, 1-48.

Becker C.D., Genoway R.G., 1979, Evaluation of the critical thermal maximum for determining thermal tolerance of freshwater-fish. Environ. Biol. Fish. 4, 245-256.

Béguer M., Beaulaton L., Rochard E., 2007, Distribution and richness of diadromous fish assemblages in Western Europe: large scale explanatory factors. Ecol. Freshw. Fish 16, 221-237.

Blaxter J.H.S., 1992, The effect of temperature on larval fishes. Neth. J. Zool. 42, 336-357.

Boisneau C., Moatar F., Bodin M., Boisneau P., 2008, Does global warming impact on migration patterns and recruitment of Allis shad (Alosa alosa L.) young of the year in the Loire River, France. Hydrobiologia 602, 179-186.

Brown J.H., Gillooly J.F., Allen A.P., Savage V.M., West G.B., 2004, Toward a metabolic theory of ecology. Ecology 85, 1771-1789.

Cassou-Leins J.J., Cassou-Leins F., Boisneau P., Bagliniere J.L., 2000, La reproduction. In: J.L. B., P. E. (Eds.), Les aloses (Alosa alosa et Alosa fallax spp.) "Ecobiologie et variabilité des populations". Paris, INRA Cemagref, pp. 73-92.

Chanseau M., Castelnaud G., Carry L., Martin Vandembulcke D., Belaud A., 2005, Essai d'évaluation du stock de géniteurs d'alose Alosa alosa du bassin versant Gironde-Garonne-Dordogne sur la période 1987-2001 et comparaison de différents indicateurs d'abondance. Bull. Fr. Pech. Piscic. 374, 1-19.

Chittenden M.E., 1972, Response of young American shad, Alosa sapidissima, to low temperature. Trans. Am. Fish. Soc. 101, 680 685.

Coutant C.C., 1987, Thermal preference: when does an asset become a liability? Environ. Biol. Fish. 18, 161-172.

Cox D.R., Oakes D., 1984, Analysis of survival data. CRC Press.

Crecco V., Savoy T., Gunn L., 1983, Daily mortality rates of larval and juvenile American shad (Alosa sapidissima) in the Connecticut River with changes in year-class strengh. Can. J. Fish. Aquat. Sci. 40, 1719-1728.

Crecco V.A., Savoy T.F., 1984, Effects of fluctuations in hydrographic conditions on year-class strength of American shad (Alosa sapidissima) in the Connecticut river. Can. J. Fish. Aquat. Sci. 41, 1216-1223. 
Crecco V.A., Savoy T.F., 1985, Effects of biotic and abiotic factors on growth and relative survival of young American shad, Alosa sapidissima in the Connecticut river. Can. J. Fish. Aquat. Sci. 42, $1640-1648$

Delage N., Cachot J., Rochard E., Fraty R., Jatteau P., 2014, Hypoxia tolerance of European sturgeon (Acipenser sturio L., 1758) young stages at two temperatures. J. Appl. Ichthyol. 30, 1195-1202.

Edsall T.A., 1970, The effect of temperature on the rate of development and survival of Alewife egss and larvae. Trans. Am. Fish. Soc. 99, 376-380.

Elliott J.M., Elliott J.A., 2010, Temperature requirements of Atlantic salmon Salmo salar, brown trout Salmo trutta and Arctic charr Salvelinus alpinus: Predicting the effects of climate change. J. Fish Biol. 77, 1793-1817.

Esteves E., Andrade J.P., 2008, Diel and seasonal distribution patterns of eggs, embryos and larvae of twaite shad Alosa fallax fallax (Lacépède, 1803) in a lowland tidal river. Acta Oecol. 34, 172185.

Esteves E., Andrade J.P., 2012, Intrannual effects of biotic and abiotic factors on growth and mortality of anadromous twaite shad, alosa fallax fallax (Lacépède, 1803), larvae. In: Pourali K., Raad V.N. (Eds.), Larvae: Morphology, Biology and Life Cycle, Nova Science Publishers, Inc., pp. 57-82.

Fletcher J.W., Millard M., Mohler J.W., King K., 2001, Tank spawning techniques: relative efficacy of 2 hormones for inducing spawning in American Shad. In: Susquehanna River Anadromous Fish Restoration Committee (Ed.) Restoration of American Shad to the Susquehanna River. Harrisburg, PA, US Fish and Wildlife Service, pp. 47-60.

Frederich M., Pörtner H.O., 2000, Oxygen limitation of thermal tolerance defined by cardiac and ventilatory performance in spider crab, Maja squinado. Am. J. Physiol. Regulator- Integrative Comp. Physiol. 279, R1531-R1538.

Heinrich J.W., 1981, Culture, feeding, and growth of alewiwes hatched in the laboratory. Prog. Fish-Cult. 43, 3-7.

Hendricks M.L., 2003, Culture and transplant of alosines in North America. In: Limburg K.E., Waldman J.R. (Eds.), Biodiversity, status and conservation of the world's shads. Bethesda, Maryland, American Fisheries Society Symposium 35, pp. 303-312.

Hendricks M.L., Tryninewski J.D., 2009, American shad hatchery operation 2008. In: Susquehanna River Anadromous Fish Restoration Committee (Ed.) Restoration of American shad to the Susquehana River Harrisburg, PA, US Fish and Wildlife Service, pp. $1-25$.

Huey R.B., Stevenson R.D., 1979, Integrating Thermal Physiology and Ecology of Ectotherms - Discussion of Approaches. Amer. Zool. 19, 357-366.

Hughes L., 2000, Biological consequences of global warming: Is the signal already apparent? Trends Ecol. Evol. 15, 56-61.

Hundt M., Schiffer M., Weiss M., Schreiber B., Kreiss C.M., Schulz R., Gergs R., 2015, Effect of temperature on growth, survival and respiratory rate of larval allis shad Alosa alosa. Knowl. Manag. Aquat. Ecosyst. 416, 27.

ICES, 2015, Report of the workshop on lampreys and shads Copenhagen, Denmark, International Council for the Exploitation of the Sea (ICES), p. 206.

Jatteau P., Fraty R., 2012, Etude de la tolérance à l'hypoxie des juvéniles de grande alose (alosa alosa). Cestas, IRSTEA, p. 18

Kamler E., Keckeis H., Bauer-Nemeschkal E., 1998, Temperatureinduced changes of survival, development and yolk partitioning in Chondrostoma nasus. J. Fish Biol. 53, 658-682.

Kellogg R.L., 1982, Temperature requirements for the survival and early development of the anadromous alewife. Prog. Fish-Cult. $44,63-73$.
Klauda R.J., Fischer S.A., Hall L.W., Jr., Sullivan J.A., 1991, American shad and hickory shad Alosa sapidissima and Alosa mediocris. In: Funderburk S.L., Jordan S.J., Mihursky J.A., Riley D. (Eds.), Habitat requirements for Chesapeake Bay living resources. Annapolis, MD, Chesapeake Bay Program, pp. 9-1-927.

Lanoux A., Etcheber H., Schmidt S., Sottolichio A., Chabaud G., Richard M., Abril G., 2013, Factors contributing to hypoxia in a highly turbid, macrotidal estuary (the Gironde, France). Environmental Science-Processes \& Impacts 15, 585-595.

Lassalle G., Béguer M., Beaulaton L., Rochard E., 2008, Diadromous fish conservation plans need to consider global warming issues: An approach using biogeographical models. Biol. Conserv. 141, 1105-1118.

Leggett W.C., Whitney R.R., 1972, Water temperature and the migrations of American shad. Fish. Bull. 70, 659-670.

Limburg K.E., 2001, Through the gauntlet again: Demographic restructuring of American shad by migration. Ecology 82, 15841596.

Manel S., Debouzie D., 1997, Logistic regression and continuation ratio models to estimate insect development under variable temperatures. Ecol. Modelling 98, 237-243.

Martin Vandembulcke D., 1999, Dynamique de la population de la grande alose (Alosa alosa L. 1758) dans le bassin versant Gironde - Garonne - Dordogne (France) : analyse et prévision par modélisation. Toulouse, Université de Toulouse, p. 115.

Navarro T., Carrapato C., Ribeiro F., 2014, Effects of temperature, salinity and feeding frequency on growth and mortality of twaite shad (Alosa fallax) larvae. Knowl. Managt. Aquatic Ecosyst. 412, 07.

Rochard E., 2001, Migration anadrome estuarienne des géniteurs de grande alose Alosa alosa, allure du phénomène et influence du rythme des marées. Bull. Fr. Pech. Piscic. 362/363, 853-867.

Ross R.M., Bennett R.M., Backman T.W., 1993, Habitat use by spawning adult, egg and larval American shad in the Delaware River. Rivers 4, 227-238.

Rosso L., Lobry J.R., Bajard S., Flandrois J.P., 1995, Convenient model to describe the combined effects of temperature and ph on microbial-growth. Appl. Environ. Microbiol. 61, 610-616.

Rougier T., Drouineau H., Dumoulin N., Faure T., Deffuant G., Rochard E., Lambert P., 2014, The GR3D model, a tool to explore the Global Repositioning Dynamics of Diadromous fish Distribution. Ecol. Modelling 283, 31-44.

Rougier T., Lambert P., Drouineau H., Girardin M., Castelnaud G., Carry L., 2012, Collapse of Allis shad, Alosa alosa, in the Gironde system (southwest France): environmental change, fishing mortality, or Allee effect? ICES J. Mar. Sci. 69, 1802-1811.

Sabatie R., Bagliniere J.L., 2001, Some ecobiological traits in Morrocan shads; A cultural and socio-economic value interest which has disappeared. Bull. Fr. Pech. Piscic. 362/363, 903-917.

Savoy T., Crecco V., 1988, The timing and significance of densitydependant and density-independant mortality of American shad Alosa sapidissima. Fish. Bull. 88, 467-482.

Shelford V.E., 1931, Some Concepts of Bioecology. Ecology 12, 455467.

Souchon Y., Tissot L., 2012, Synthesis of thermal tolerances of the common freshwater fish species in large Western Europe rivers. Knowl. Manag. Aquat. Ecosyst. 405, 10.1051/kmae/2012008.

Stratoudakis Y., Mateus C.S., Quintella B.R., Antunes C., Raposo de Almeida P., 2016, Exploited anadromous fish in Portugal: Suggested direction for conservation and management. Mar. Policy 73, 92-99. 
Taverny C., 1991, Contribution à la connaissance de la dynamique des populations d'aloses (Alosa alosa et Alosa fallax) dans le système fluvio-estuarien de la Gironde : pêche, biologie et écologie - Etude particulière de la dévalaison et de l'impact des activités humaines, Université de Bordeaux I, p. 451.

Taverny C., Belaud A., Elie P., Sabatie M.R., 2000a, Influence des activités humaines. In: Baglinière J.L., Elie P. (Eds.), Les aloses (Alosa alosa et Alosa fallax spp.) : écobiologie et variabilité des populations. Paris, INRA - Cemagref, pp. 227-248.

Taverny C., Cassou-Leins J.J., Cassou-Leins F., Elie P., 2000b, De l'oeuf à l'adulte en mer. In: Baglinière J.L., Elie P. (Eds.), Les aloses (Alosa alosa et Alosa fallax spp.): écobiologie et variabilité des populations. Paris, INRA - CEMAGREF, pp. 93-124.

Teletchea F., Fontaine P., 2010, Comparison of early life-stage strategies in temperate freshwater fish species: trade-offs are directed towards first feeding of larvae in spring and early summer. J. Fish Biol. 77, 257-278.
Therneau, T., 2015, A package for survival analysis in S. Version 2.38; http://CRAN.R-project.org/package $=$ survival .

Thornton K.W., Lessem A.S., 1978, A temperature algorithm for modifying biological rates. Trans. Am. Fish. Soc. 107, 284-287.

Walsh H.J., Settle L.R., Peters D.S., 2005, Early life history of blueback herring and alewife in the lower Roanoke River, North Carolina. Trans. Am. Fish. Soc. 134, 910-926.

Wehrly K., Wang L., Mitro M.G., 2007, Field-based estimates of thermal tolerance limits for trout: incorporating exposure time and temperature fluctuation. Trans. Am. Fish. Soc. 136, 365-374.

Wiggins T.A., Bender T.R., Mudrak V.A., Coll J.A., 1985, The development, feeding, growth and survival of cultured American shad larvae through the transition from endogenous to exogenous nutrition. Prog. Fish-Cult. 47, 87-93.

Ziegeweid J.R., Jennings C.A., Peterson D.L., 2008, Thermal maxima for juvenile shortnose sturgeon acclimated to different temperatures. Environ. Biol. Fish. 82, 299-307. 